Alkaline phosphatase calcium growth rate

ionized calcium magnesium parathyroid hormone phosphorus skeletal development

\title{
Serum Parathyroid Hormone and Blood Minerals: Interrelationships in Normal Children
}

\author{
SARA B. ARNAUD ${ }^{1631}$, RALPH S. GOLDSMITH, GUNNAR B. STICKLER, \\ JOHN T. MCCALL, AND CLAUDE D. ARNAUD \\ Mayo Clinic and Mayo Foundation, Rochester, Minnesota, USA
}

\begin{abstract}
Extract
Simultaneous measurements of immunoreactive parathyroid hormone (iPTH), calcium, magnesium, phosphorus, and alkaline phosphatase in serum were performed in 120 normal subjects who ranged from 6 months to 20 years of age. When plotted as a function of age, these extracellular indices of calcium homeostasis showed changes throughout the growth period and differences in their interrelationships in early childhood, middle childhood, and adolescence. Mean serum concentration of minerals was highest during early childhood and decreased parallel to decreases in iPTH and alkaline phosphatase. Between the ages of 6 and 12 years, calcium, magnesium, and phosphorus tended to plateau, iPTH was lower, and alkaline phosphatase increased. During adolescence, calcium, phosphorus, and alkaline phosphatase decreased to adult values, magnesium showed no change, and $\mathrm{iPTH}$ increased to adult values.

Plasma ionized calcium, which was higher in middle childhood (mean, $4.59 \mathrm{mg}$ / $100 \mathrm{ml}$ ) than at ages 12 to 20 years (mean, $4.33 \mathrm{mg} / 100 \mathrm{ml}$ ), showed the expected negative correlation with iPTH $(P<0.005)$. Total serum calcium did not correlate with iPTH; however, the pattern of decrease of serum calcium with age was similar to growth velocity curves, especially in girls, in whom mean serum calcium was higher $(9.93 \mathrm{mg} / 100 \mathrm{ml})$ between 8 and 16 years than in boys $(9.75 \mathrm{mg} / 100$ $\mathrm{ml})$.
\end{abstract}

\section{Speculation}

Parathyroid hormone is important in maintaining the concentration of plasma ionized calcium in normal children, but the regulation of total serum calcium is different from that in adults. The total serum calcium or factors regulating it may have a direct or indirect influence on the growth process.

\section{Introduction}

The circulating parathyroid hormone concentration, as measured by a sensitive radioimmunoassay, is inversely related to the concentration of total serum calcium in adult man [3] and animals [2,32] and is not directly related to the serum phosphorus concentration if normocalcemia is maintained [32]. Young children have higher concentrations of serum calcium [16, 34] and phosphorus [11, 34, 41] than do adults, but the relationships between iPTH and these minerals have not been examined in well children. This study was done to determine the normal range and variation of serum iPTH and of the minerals influencing its secretion under steady state conditions in children. Our 


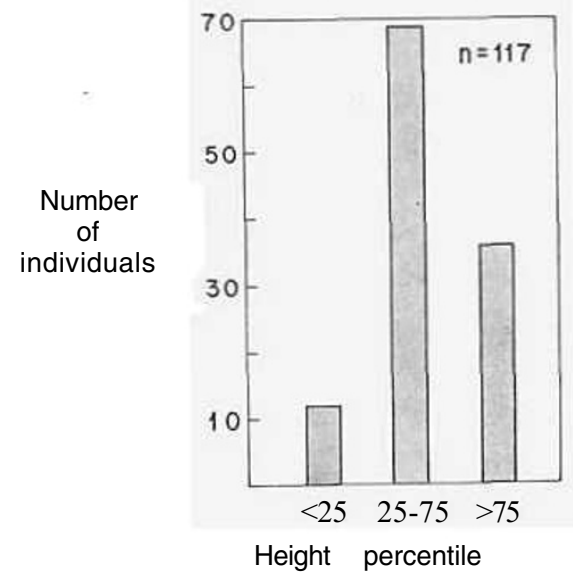

Fig. 1. Height percentile of subjects, estimated according to Reed-Stuart [29] tables.

results provide normative data which can be used for the study of disorders of calcium metabolism and also show interrelationships among these parameters of calcium homeostasis which may have importance in the basic understanding of skeletal growth.

\section{Methods and Materials}

\section{Study Subjects}

We studied 120 clinically well children and young adults from 6 months to 20 years of age; 116 were Caucasian and 4 were Negro. Height and weight were recorded for all but three of the subjects. The sample was taller than average when compared with standard growth charts [29] (Fig. 1), and all subjects were at or over the third percentile. "Volunteers" were 66 healthy offspring of hospital and laboratory personnel who were seen specifically for the study. Informed consent was obtained from all the parents and all volunteers over 6 years of age. "Outpatients" were 54 clinically well outpatients who were referred to the Mayo Clinic Department of Pediatrics for diagnostic evaluation of problems unrelated to skeletal disease. All outpatients had normal hemograms and normal results on urinalysis; none was receiving medication. These studies were done between October 1970 and January 1972.

\section{Analytical Methods}

Ten to $15 \mathrm{ml}$ of venous blood were drawn, with application of a tourniquet for $60 \mathrm{sec}$, from a fasting study subject between 7:30 and 9:00 AM. The blood was collected into a syringe and then placed in unopened Vacutainers [43] containing either heparin or no anticoagulant.
Total serum calcium and magnesium were measured by atomic absorption spectrometry [44]. Ionized calcium was determined on fresh plasma withdrawn anaerobically into a tuberculin syringe through the rubber stopper of a completely filled 5-ml Vacutainer (containing $143 \mathrm{U}$ of heparin) after centrifugation at $3,000 \mathrm{rpm}$ for $10 \mathrm{~min}$. The Orion flow-through calcium activity electrode [23,37, 45] was used with the following modifications: (1) standards were prepared in Vacutainers containing the same amount of heparin as did samples, (2) no trypsin or triethanolamine was added to the standards, which were prepared weekly, and (3) the membrane was primed by pooled normal plasma before the daily standard curve was run. Total protein was determined on plasma with an American Optical refractometer [46]; plasma $\mathrm{pH}$ was measured by a microelectrode and a standard $\mathrm{pH}$ meter. Serum phosphorus was determined by the method of Young [42] modified by manual precipitation of protein with $10 \%$ trichloroacetic acid prior to the AutoAnalyzer [47] determination. Alkaline phosphatase was measured by using the Sigma 104-5 kit [48] based on the Bessey et al. method [4] with disodium p-nitrophenylphosphate as substrate, nitrophenol as standard, and Enza-Trol [49] as a continuing check on quality control.

Serum iPTH was measured by a sensitive radioimmunoassay [3] which uses (7) guinea pig anti-porcinePTH antiserum $\left(1: 100,000\right.$, GP-1M), (2) ${ }^{\text {lsl }}$ I-labeled bovine parathyroid hormone, and (3) human hyperparathyroid serum as a reference standard. The immunoreactive species of parathyroid hormone which this assay measures in $95 \%$ of normal adult sera is undetectable in hypoparathyroid sera and is increased over $40 \mathrm{fj}$. eq/ml [50] in $90 \%$ of hyperparathyroid sera [3, 27]. GP-1M antiserum reacts with all currently known circulating species of parathyroid hormone [10]. Each serum sample was assayed in three dilutions $(200,100$, and $50 / \mathrm{J} / 500-/ \mathrm{xl}$ incubation volume). The values obtained agreed within $14 \%$, and $80 \%$ of the values reported represent averages of the values obtained with either two or three dilutions of serum. The interassay coefficient of variation of replicate determinations of values which felj in the midportion of the standard curve was $12 \%$; for those which fell in the lower portions of the standard curve (above $85 \%$, see below) the coefficient was $20 \%$. The iPTH value was considered undetectable only in serum which resulted in a ratio of antibody-bound to unbound ${ }^{131}$ I-labeled bovine PTH (B/F ratio) greater than $85 \%$ of the $\mathrm{B} / \mathrm{F}$ ratio in controls of hypoparathyroid serum $(<5 / \mathrm{J}$ eq/ml). In $20 \%$ 


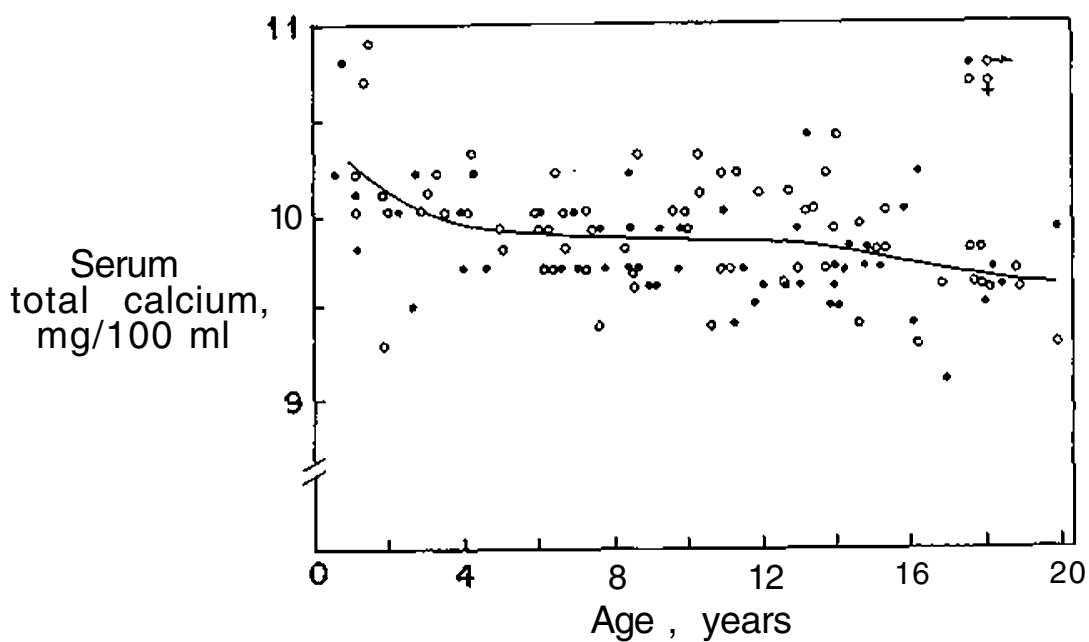

Fig. 2. Best fit curve of serum total calcium as a function of age. from 8 to 16 years.

of sera, iPTH was detectable only in the 200-/J sample, and this is the value reported; however, it was required that the next lower serum dilution $(100 / \mathrm{J} / 500-$ , ${ }^{*}$ incubation volume) of these sera result in a $\mathrm{B} / \mathrm{F}$ ratio equal to that of hypoparathyroid control serum. This latter precaution was observed in order to minimize the potential of nonspecific influences of serum on the immune system. Using these criteria, iPTH was considered measurable in greater than $94 \%$ of the sera studied.

\section{Statistical Analysis}

Estimates of central tendency were calculated by pooling the data in 2-year age groupings $(n=8-18)$, the only deviation from this practice being the pooling of ages 6 months to 2 years $(n=10)$ and of 16-20 years $\{n=17$ ). Differences between age groups were evaluated statistically by Dunnett's test [7], which provides for multiple comparisons with a control group. In this case, the age group 16-20 years was considered as the reference or control group, since mean values of all variables studied were essentially identical with those of adults [3, 18]. Differences between boys and girls of like age were evaluated by the nonpaired Student $t$ test. Product-moment correlation and regression analysis were performed by standard techniques [33]. For curvilinear regressions, successive terms were added to the polynomial equation so long as each addition was statistically significant by analysis of variance. Stepwise multiple regression analysis was performed by adding one variable to the regression at each step. The variable added is the one which makes the greatest decrease in the error sum of squares; equivalently, it is the variable which has the highest partial correlation with the dependent variable partialed on the variables which have already been added.

\section{Results}

\section{Total Serum Calcium}

Mean total serum calcium was highest $(10.2 \mathrm{mg} / 100$ $\mathrm{ml})$ in the youngest age group (0.5-2 years) studied, decreased to a plateau by 6-8 years, and decreased to an adult value $(9.6 \mathrm{mg} / 100 \mathrm{ml})$ at $16-20$ years (Fig. 2). Different methods of measurement [38] probably account for the values being slightly lower than those previously published $[16,24,34,41]$, but the narrow range of normal values within each age group is similar $(1.4 \mathrm{mg} / 100 \mathrm{ml})$ [16]. By Dunnett's test, only children less than 6 years old had a significantly higher mean serum calcium than those in age group 16-20 years, but the entire population showed significant age dependency $(\mathrm{r}=0.473 ; P<0.001)$. Total protein was significantly correlated with total calcium ( $\mathrm{r}=$ $+0.263 ; P<0.025)$ in the 60 subjects in whom both were measured. In the youngest children ( 6 months- 6 years), the total protein concentration was not increased compared with older groups, which indicates that the higher serum calcium in this age group was not caused by an artifact of venous stasis during venipuncture [6]. Sex differences in total serum calcium were observed only at ages 8-16 $(9.75 \pm 0.36$ in males vs $9.93 \pm 0.46 \mathrm{mg} / 100 \mathrm{ml}$ in females; $P<0.01$ ). A similar observation was recently reported by Tumble- 
Table I. Parameters of calcium homeostasis ${ }^{1}$

\begin{tabular}{|c|c|c|c|c|c|c|c|}
\hline Age group, yr & $\begin{array}{l}\text { Serum Ca, } \\
\mathrm{mg} / 100 \mathrm{ml}\end{array}$ & $\begin{array}{l}\text { Serum Mg, } \\
\mathrm{mg} / 100 \mathrm{ml}\end{array}$ & $\begin{array}{l}\text { Serum } \mathrm{P} \\
\mathrm{mg} / 100 \mathrm{ml}\end{array}$ & $\underset{\mathrm{mg} / 100 \mathrm{ml}}{\text { Plasma ionized Ca, }}$ & $\begin{array}{l}\text { Total protein, } \\
\mathrm{g} / 100 \mathrm{ml}\end{array}$ & $\underset{l i l \mathrm{eq} / \mathrm{ml}^{3}}{\mathrm{iPTH}, 2}$ & $\underset{\mathrm{IU} / \text { /liters }}{\text { Alkaline }}$ \\
\hline \multirow[t]{2}{*}{$0.5-6$} & 10.05 & 2.00 & 5.65 & $4.41(n=7)$ & $6.81(n=7)$ & 22 & 83 \\
\hline & \pm 0.70 & \pm 0.28 & \pm 1.62 & \pm 0.50 & \pm 0.30 & ND"-56 & $39-141$ \\
\hline \multirow[t]{2}{*}{$6-12$} & 9.84 & 1.90 & 5.09 & 4.59 & 7.02 & 16 & 91 \\
\hline & \pm 0.46 & \pm 0.22 & \pm 1.14 & \pm 0.52 & \pm 0.66 & $N^{5}-34$ & $41-155$ \\
\hline \multirow[t]{2}{*}{$12-20$} & 9.75 & 1.89 & 4.78 & 4.33 & 7.06 & 20 & 53 \\
\hline & \pm 0.54 & \pm 0.26 & \pm 1.52 & \pm 0.50 & \pm 0.60 & $\mathrm{ND}<\mathrm{M} 4$ & $10-145$ \\
\hline
\end{tabular}

${ }^{1}$ Shown as mean \pm 2 SD in each group, $n$ : Shown in Table II. Sex distribution ranged from $1: 1$ to 3:2.

2 iPTH: Immunoreactive parathyroid hormone.

${ }^{3}$ Range used because of logarithmic mean and skewed distribution.

${ }^{4}$ Not detectable in $4 \%$ of population sample.

${ }^{5}$ Not detectable in $9 \%$ of population sample.

${ }^{6}$ Not detectable in $2 \%$ of population sample.

Table II. $n$ for parameters of calcium homeostasis ${ }^{1}$

\begin{tabular}{|c|c|c|c|c|c|c|c|}
\hline Age group, & $\begin{array}{c}\text { Serum } \\
\mathbf{C a} \text {, } \\
100 \mathrm{ml}\end{array}$ & $\begin{array}{c}\text { Serum } \\
\mathrm{Mg}, \\
\mathrm{mg} / \\
100 \mathrm{ml}\end{array}$ & $\begin{array}{c}\text { Serum } \\
\mathrm{P}, \\
\mathrm{mg} / \\
100 \mathrm{ml}\end{array}$ & $\begin{array}{c}\text { Plasma- } \\
\text { ionized } \\
\mathrm{Ca}, \mathrm{mg} / \\
100 \mathrm{ml}\end{array}$ & $\begin{array}{c}\text { Total } \\
\text { protein, } \\
\mathrm{g} / 100 \\
\mathrm{ml}\end{array}$ & $\begin{array}{c}\mathrm{iPTH}, \\
\mu \mathrm{l} \\
\mathrm{e} / \mathrm{ml}\end{array}$ & $\begin{array}{l}\text { Alkaline } \\
\text { phos- } \\
\text { phatase, } \\
\text { IU/liter }\end{array}$ \\
\hline $0.5-6$ & 27 & 20 & 23 & 7 & 7 & 27 & 19 \\
\hline Male & 13 & 11 & 12 & 5 & 5 & 13 & 9 \\
\hline Female & 14 & 9 & 11 & 2 & 2 & 14 & 10 \\
\hline 6-12 & 45 & 40 & 44 & 28 & 28 & 45 & 40 \\
\hline Male & 21 & 20 & 21 & 13 & 13 & 21 & 16 \\
\hline Female & 24 & 20 & 23 & 15 & 15 & 24 & 24 \\
\hline $12-20$ & 47 & 39 & 46 & 32 & 32 & 48 & 41 \\
\hline Male & 21 & 17 & 22 & 14 & 14 & 22 & 20 \\
\hline Female & 26 & 22 & 24 & 18 & 18 & 26 & 21 \\
\hline
\end{tabular}

${ }^{1}$ IPTH: Immunoreactive parathyroid hormone.

son et al. [39], who noted an increase in total serum calcium a few months before skeletal maturity in female miniature pigs but not in males. The data of Keating et al. [18], from normal adults 20-80 years of age, which show a significant regression of serum calcium with age in men $(y=9.79-0.0068 x)$ but not women $(y-9.41+0.0005 \mathrm{x})$, suggest that men 20-30 years old have higher serum calcium values than do women of that age, the opposite of our observation in the preceding decade (Tables I and II).

\section{Ionized Calcium}

Plasma ionized calcium was determined in the 66 volunteers. With the exception of the six children who were less than 6 years old, the pattern of ionized calcium with age was like that for total calcium. Mean ionized calcium was $4.48 \mathrm{mg} / 100 \mathrm{ml}$ between ages 6 and 16 years and decreased to $4.22 \mathrm{mg} / 100 \mathrm{ml}$ in age group $16-20$ years $(P<0.001)$. Sachs et al. [31] reported no significant difference in a smaller number of French children $(4.4 \mathrm{mg} / 100 \mathrm{ml} v \mathrm{vs} 4.2 \mathrm{mg} / 100 \mathrm{ml}$ in adults). Comparison of plasma ionized calcium concentration in seven pairs of children and their adult relatives showed consistently higher $(0.09-0.47 \mathrm{mg} / 100 \mathrm{ml})$ values in the children. The ionized calcium ranged from $39-47 \%$ of total calcium in individual samples, as reported in normal adults [14, 23]. Nevertheless, plasma ionized calcium did not correlate with total calcium, a phenomenon noted by others in sera from adults [12, 14, 23] but not in neonates [28]. Fasting serum phosphorus was correlated positively with both total serum calcium $(\mathrm{r}=+0.314 ; P<0.001)$ and with ionized calcium $(\mathrm{r}=+0.322 ; P<0.025)$, a situation opposite that observed in acute studies of infusion or dietary load of phosphate $[14,30]$ and indicative of age dependency and the difference between the steady state and acutely perturbed relationships of both these elements in the blood.

\section{Serum Magnesium}

Serum magnesium decreased from a mean $( \pm 2 \mathrm{SD})$ of $2.16 \pm 0.16 \mathrm{mg} / 100 \mathrm{ml}$ in the youngest 2-year age grouping to $1.91 \pm 0.24 \mathrm{mg} / 100 \mathrm{ml}$ in the 4-6-year age group; thereafter it showed no change.

\section{Serum Phosphorus (Inorganic Phosphate)}

Serum phosphorus showed an age dependency like that for calcium $(\mathrm{r}=+0.314 ; P<0.025)$, but with a much greater decrease between infancy and adulthood (Fig. 3). For the entire population, only the linear term of the least squares regression was significant $(\mathrm{r}=$ $-0.504 ; P<0.001)$, with a slope of $-0.076 \mathrm{mg} / 100$ $\mathrm{ml} /$ year of age. The pattern of change with age, however, showed greatest decreases in the youngest children (0.5-4 years) and at adolescence (12-16 years). 


\section{Serum iPTH}

The best fit curve for serum iPTH (Fig. 4) showed a significant quadratic regression $(\mathrm{r}=0.309 ; P<0.025)$ on age. Mean values were generally highest in the youngest children, decreased to a nadir at about ages 7-9 years, and then increased gradually to a plateau at adolescence. Mean serum iPTH between ages 14 and 20 years was $22 / \mathrm{J} \mathrm{eq} / \mathrm{ml}$, identical with that observed in adults. No significant differences in mean values between boys and girls were observed, although the nadir in boys occurred slightly later (age 11 years) than that in girls (age 9 years).

Serum iPTH showed no significant correlation with total serum calcium, although comparison of Figures 2

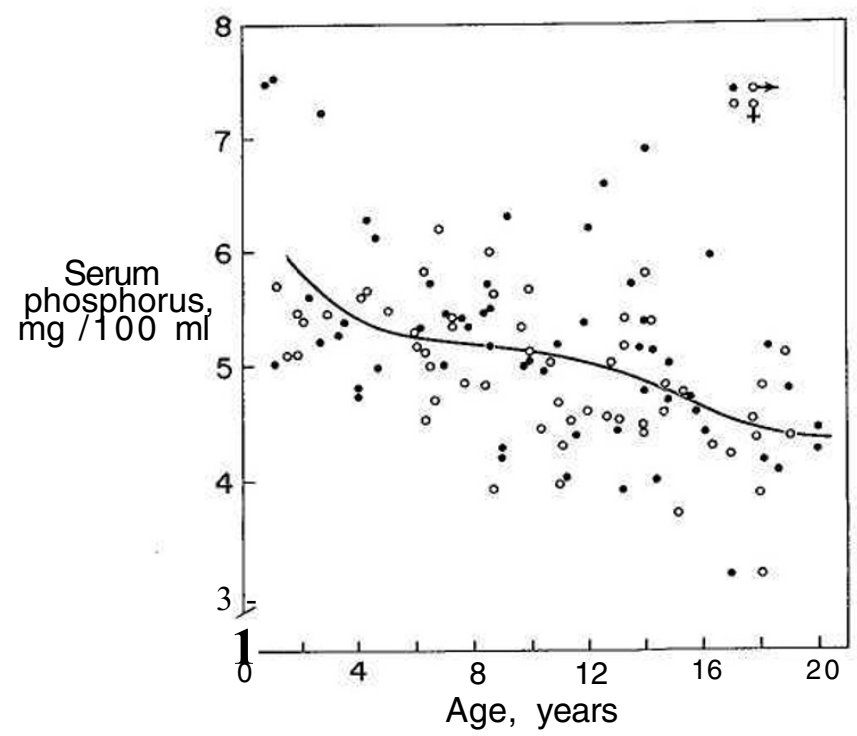

Fig. 3. Best fit curve of serum phosphorus as a function of age. «: Boys; $Q$ : girls. and 4 discloses relationships which differ before and after age 6 years, the latter one being similar to that observed in adults [3]. In the 66 children in whom both serum iPTH and ionized calcium were estimated, a significant negative correlation was observed $(\mathrm{r}$ -0.420; $P<0.005$ ) (Fig. 5). Ten percent of these children were under 6 years of ags. Serum phosphorus correlated negatively with iPTH only in children older than 6 years $(\mathrm{r}=-0.290 ; P<0.01)$. The coincident adolescent (12-16 years) decrease in serum phosphorus and increase in serum iPTH is compatible with a physiologic role of parathyroid hormone in maintaining the concentration of serum phosphorus $[1,13]$. The adolescent increase in iPTH also parallels changes in parathyroid gland size between 10 and 20 years, noted by Kurokawa [20].

\section{Serum Alkaline Phosphatase}

Of all of the variables examined, serum alkaline phosphatase activity showed the most striking changes with age (Fig. 6). Values were high in the youngest children, decreased slightly at about age 4 , increased prior to adolescence, and then decreased during adolescence to reach adult values by age $18-20$ years. The best fit curve, calculated from the logarithmic values to provide homogeneity of variance, is nearly identical with the well known graph of Clark and Beck [5] of change in plasma alkaline phosphatase in growing children; the small quantitative differences are due to pooling of data from males and females and to the mathematical techniques of curve fitting. We believe that this mathematical technique is more suitable for the small number of observations at each age because it does not require arbitrary age grouping. Values for

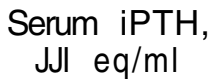

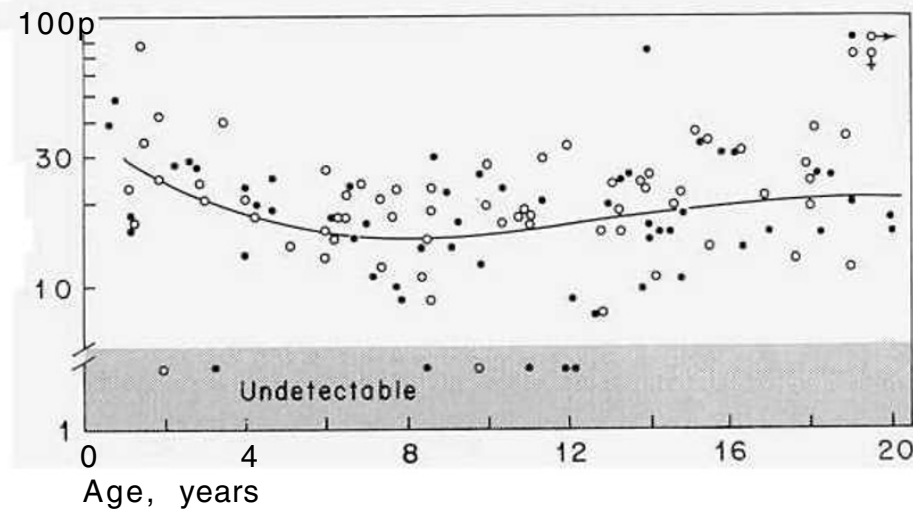

Fig. 4. Best fit curve of serum immunoreactive parathyroid hormone (logarithmic scale) (GP-1M antiserum) as a function of age. Units are microliter equivalents of standard hyperparathyroid serum $(1,000 / A \mathrm{eq} / \mathrm{ml})$. Undetectable values are taken as $5 / A$ eq/ml, the limit of sensitivity of the assay, for calculation of mean. • : Boys; O: girls. 


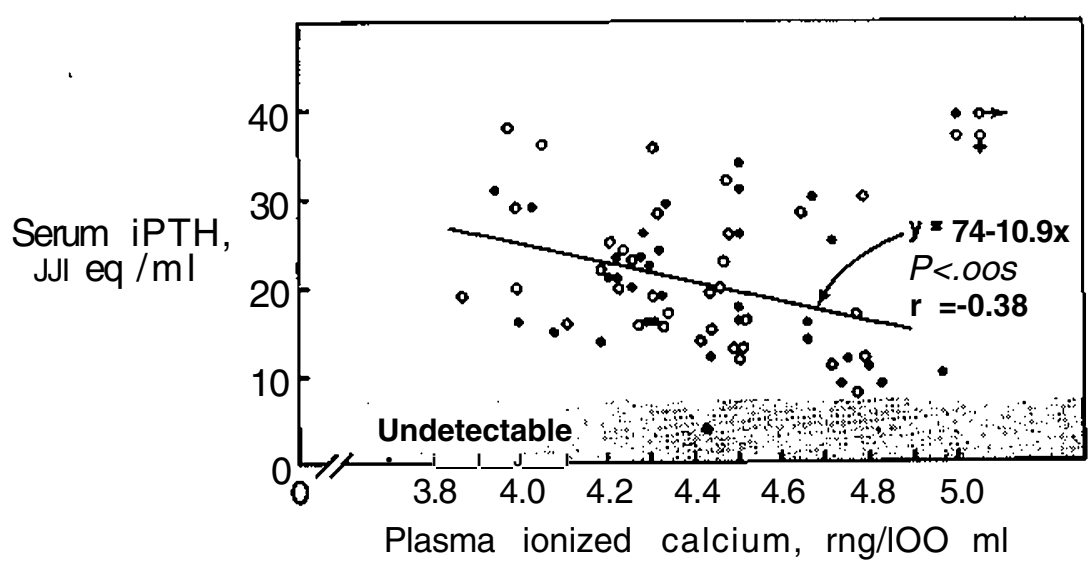

Fig. 5. Relationship of serum immunoreactive parathyroid hormone to plasma ionized calcium in 66 volunteers. •: Boys; O: girls.

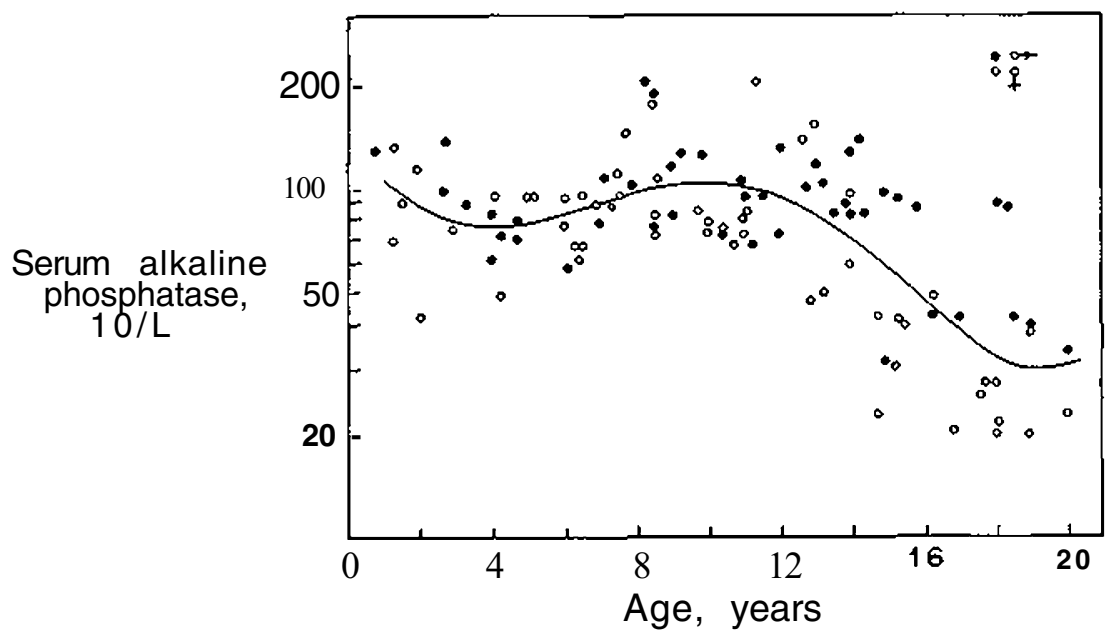

Fig. 6. Best fit curve of serum alkaline phosphatase (logarithmic scale) as a function of age. Note predominance cf values for boys above mean curve and values for girls below. - : Boys; O: girls.

Table III. Correlation of growth velocity data (from literature) with serum calcium, phosphorus, alkaline phosphatase, and parathyroid hormone

\begin{tabular}{|c|c|c|c|c|}
\hline \multirow{3}{*}{$\begin{array}{l}\text { Presumptive } \\
\text { growth } \\
\text { velocity vs }\end{array}$} & \multicolumn{4}{|c|}{ Correlation coefficients 1} \\
\hline & \multicolumn{2}{|c|}{ Boys } & \multicolumn{2}{|c|}{ Girls } \\
\hline & $\begin{array}{c}\text { Tanner } \\
\text { el al. }[36] \\
n=8\end{array}$ & $\begin{array}{l}\text { Falkner }[8] \\
\|=9\end{array}$ & $\begin{array}{l}\text { Tanner } \\
\text { el al. }[36] \\
»=8\end{array}$ & $\underset{n=9}{\text { Falkner }}[8]$ \\
\hline Serum calcium & $+0.93^{2}$ & $+0.90^{2}$ & $+0.83^{3}$ & $+0.91^{2}$ \\
\hline $\begin{array}{l}\text { Serum phospho- } \\
\text { rus }\end{array}$ & $+0.95^{2}$ & $+0.93^{2}$ & +0.59 & $+0.64^{\wedge}$ \\
\hline $\begin{array}{l}\text { Serum alkaline } \\
\text { phosphatase }\end{array}$ & $+0.72^{4}$ & $+0.71<$ & $+0.77^{4}$ & $+0.68^{4}$ \\
\hline Serum iPTH & +0.49 & +0.61 & +0.42 & +0.40 \\
\hline
\end{tabular}

${ }^{1}$ Correlations were made with average annual height increment at age of mean value for calcium homeostasis data and mean value at same age point for serum calcium, phosphorus, alkaline phosphatase, and iPTH.

${ }^{2} P<0.001$.

${ }^{3} P<0.01$

${ }^{4} P<0.05$. boys and girls plotted separately show a peak which is later in boys (age 13 years) than in girls (age 9 years).

Serum alkaline phosphatase was correlated with total calcium $(\mathrm{r}=+0.233 ; P<0.05)$, ionized calcium $(\mathrm{r}=+0.455 ; P<0.001)$, magnesium $(r=+0.406 ; P$ $<0.001)$, phosphorus $(\mathrm{r}=+0.409 ; P<0.001)$, and total protein $(\mathrm{r}=0.230 ; P<0.1)$. By stepwise multiple regression analysis, however, only three of these factors contributed significantly to the alkaline phosphatase; in the order of their relative contribution to the regression sum of squares, they were ionized calcium $(\mathrm{P}<0.001)$, phosphorus $(\mathrm{P}<0.01)$, and total protein $(\mathrm{P}<0.05)$.

Correlations of Serum Calcium, Phosphorus, Alkaline Phosphatase, and Parathyroid Hormone With Presumptive Annual Height Increment

A summary of the results is presented in Table III. 


\section{Discussion}

\section{Serum Calcium and Parathyroid Hormone}

We found age-dependent changes in the mean values of serum calcium and plasma ionized calcium which have not been previously reported. The studies showing that young children normally have higher serum calcium concentrations than adults were based on small numbers of American children examined a few years before the routine commercial addition of vitamin D to milk $[16,34]$. Because our small sample is representative of every age in childhood, age-related changes are easily seen and, as shown by the best-fit curve, indicate that the serum calcium concentration is slightly higher than in the adult until age 16 . We have not specifically studied the role of factors which influence the concentration of serum calcium, such as increased turnover and retention of calcium during growth [15], dietary intake of calcium and vitamin D, hormones other than parathyroid hormone, or environmental factors. Most of the children we examined lived in moderately affluent suburban environments in a sunny temperate climate, so that our values may not be applicable for use in clinical comparison with dissimilar populations. Nevertheless, the relationships between $\mathrm{PPTH}$, serum calcium, plasma ionized calcium, and serum phosphorus which we have established for healthy children are basic to the understanding of calcium homeostasis in sick children.

In normal adults, there is a negative relationship between total serum calcium and iPTH [3] which we observed only between plasma ionized calcium fraction and serum iPTH in children. This is indicative of the negative feedback control of parathyroid gland activity by ionic calcium. The explanation for the absence of a relationship between serum total calcium and $\mathrm{iPTH}$ in children is not clear. The fraction of total calcium which is ionized is similar in adults and children, although there is no positive correlation between the two in adults $[14,23,26]$. On the other hand, the concentration of total calcium is directly correlated with total protein [22] which does not appear to change significantly during childhood [19]. The influence of steady state concentrations of serum phosphorus on the ionized fraction of plasma calcium is largely unknown [21]. The physiologic situation in children who have high concentrations of serum phosphorus and total and ionized calcium is unique and awaits further study of the partition of calcium and phosphorus in plasma.

\section{Serum Phosphorus and Parathyroid Hormone}

The high concentration of serum phosphorus in normal children and the pattern of change with age which we observed is identical with what has been described by others [11, 34]. An influence of parathyroid hormone on the concentration of serum phosphorus in children is suggested by the negative correlation between these two indices after age 6; but other humoral effects, such as those mediated by growth hormone, have not been considered here. Parallel and decreasing serum concentrations of phosphorus and $\mathrm{PPTH}$ in children less than 6 years old are not consistent with our understanding of the known effects of parathyroid hormone.

\section{Blood Minerals, Parathyroid Hormone, and Skeletal Maturation}

Our data suggest three descriptive phases of mineral homeostasis in childhood, each of which is characterized by a change in the interrelationships among the variables and corresponds approximately to a period of alteration in the roentgenographic appearance of ossification [40]. Between 6 months and about 6 years of age, most of the secondary centers of ossification appear, and linear skeletal growth decelerates; there are decreases in the serum concentrations of calcium, phosphorus, and iPTH and a relatively smaller decrease in alkaline phosphatase. In the middle childhood years, skeletal development is characterized primarily by bony penetration of cartilaginous areas, and longitudinal growth remains fairly constant; serum calcium and phosphorus tend to plateau, iPTH decreases gradually, and serum alkaline phosphatase increases. Adolescence marks the beginning of a 5- to 10-year period during which epiphyses fuse, ending longitudinal growth, and there are large gains in skeletal mass [10]. During this phase, girls show an initial increase in serum calcium followed by a decrease to adult values, a greater decrease in serum phosphorus and alkaline phosphatase, and an increase in iPTH to adult values by age 16 years. Boys, on the other hand, show a gradual decrease in calcium, and a generally parallel increase followed by a steep decrease in both phosphorus and alkaline phosphatase, and an increase in iPTH to adult values.

Throughout the period of growth, trabecular bone formation and resorption occur at different rates [17], with resulting changes in cortical thickness. Maximal remodeling rates occur in the first year of life [35], and maximal gains in cortical thickness, as well as remodeling, occur during adolescence [9]. The high serum 
iPTH concentration during early life and the increase at adolescence may reflect the extensive remodeling which occurs at these ages, but the lower concentrations during middle childhood years are not easily understood. Further studies relating bone morphology to serum iPTH in children are required to determine the role of this hormone in the formation of the normal skeleton.

\section{Growth Data and Indices of Calcium Homeostasis}

The pattern of change in total serum calcium with age resembles normal growth velocity curves [36], a relationship which is reminiscent of the report of Perris et al. [25] of parallel changes in plasma ionized calcium, growth rate, and mitotic activity of marrow and thymus in young rats. There are obvious limitations in attempting to correlate our cross-sectional data, obtained from a population with wide variation in both growth rate and stature, with average annual height gains from mixed longitudinal data obtained 4 decades ago; but the pattern of growth rate has not changed to the degree that actual size measurements have [8]. Nevertheless, we made the correlations presented in Table III in a speculative effort to relate indices of calcium homeostasis to growth. These results suggest that a careful evaluation of blood minerals may be important in any systematic study of growth failure.

\section{Summary}

Significant age-related changes were found in the serum concentrations of minerals and immunoreactive parathyroid hormone (iPTH) in 120 healthy children with normal growth and development. Compared with levels in adults, mean iPTH concentrations were higher from 6 months to 2 years of age, lower during middle childhood, and the same as adult values at adolescence. Total serum calcium values were highest in early childhood and decreased throughout the period of childhood within a narrow range $(1.4 \mathrm{mg} / 100$ $\mathrm{ml})$ at each age. Total calcium did not correlate with iPTH, but ionized calcium, which was significantly higher from 6 to 16 years than in adults, showed a significant negative correlation with iPTH $(P<$ 0.005). This suggests the physiologic importance of the negative feedback control of parathyroid gland activity by the calcium ion in childhood. High or increasing values at two periods of rapid growth, under 2 years and at adolescence, suggest participation of the parathyroid gland in the generalized growth process.

\section{References and Notes}

1. ALBRIGHT, F., AND REIFENSTEIN, E. C, JR.: The Parathyroid Glands and Metabolic Bone Disease: Selected Studies. (The Williams \& Wilkins Company, Baltimore, 1948).

2. ARNAUD, C. D., LITTLEDIKE, T., AND TSAO, H. S.: Calcium homeostasis and the simultaneous measurement of calcium and parathyroid hormone in the pig. In: Proceedings of the Second International Symposium on Calcitonin, p. 95. (William Heinemann Medical Books, Ltd., London, 1970).

3. ARNAUD, C. D., TSAO, H. S., AND LITTLEDIKE, T.: Radioimmunoassay of human parathyroid hormone in serum. J. Clin. Invest., 50: 21 (1971).

4. BESSEY, O. A., LOWRY, O. H., AND BROCK, M. J.: A method for the rapid determination of alkaline phosphatase with five cubic millimeters of serum. J. Biol. Chem., 164: 321 (1946).

5. CLARK, L. C, JR., AND BECK, E. I.: Plasma "alkaline" phosphatase activity: normative data for growing children. J. Pediat., 36: 335 (1950).

6. DENT, C. E., AND HARPER, C. M.: Plasma-alkaline-phosphatase in normal adults and in patients with primary hyperparathyroidism. Lancet, $i$ : 559 (1962).

7. DUNNETT, C. W.: A multiple comparison procedure for comparing several treatments with a control. J. Amer. Stat. Ass., 50: 1096 (1955).

8. FALKNER, F.: Some physical growth standards for white North American children. Pediatrics, 29: 467 (1962).

9. GARN, S. M., AND WAGNER, B.: The adolescent growth of the skeletal mass and its implications of mineral requirements. In: F. P. Heald: Adolescent Nutrition and Growth, p. 142. (Appleton-Century-Crofts, New York, 1969).

10. GOLDSMITH, R. S., FURSZYFER, J., JOHNSON, W. J., FOURNIER, A. E., SIZEMORE, G. W., AND ARNAUD, C. D.: Etiology of hyperparathyroidism and bone disease during chronic hemodialysis. III. Evaluation of parathyroid suppressibility. J. Clin. Invest., 52: 173 (1973).

11. GREENBERG, B. G., WINTERS, R. W., AND GRAHAM, J. B.: The normal range of serum inorganic phosphorus and its utility as a discriminant in the diagnosis of congenital hypophosphatemia. J. Clin. Endocrinol. Metabol., 20: 364 (I960).

12. HANSEN, S. O., AND THEODORSEN, L.: The usefulness of an improved calcium electrode in the measurement of ionized calcium in serum. Clin. Chim. Acta, 31: 119 (1971).

13. HARRISON, H. E., AND HARRISON, H. C: The renal excretion of inorganic phosphate in relation to the action of vitamin D and parathyroid hormone. J. Clin Invest., 20: 47 (1941).

14. HATTNER, R. S., JOHNSON, J. W., BERNSTEIN, D. S., WACHMAN, A., AND BRACKMAN, J.: Electrochemical determination of apparent ionized serum calcium using a calcium-selective electrode: The method and values in normal humans and a comparison to total serum calcium. Clin. Chim. Acta, 28: 67 (1970).

15. HOLMES, J. O.: The requirement for calcium during growth. Nutr. Abstr. Rev., 14: 597 (1945).

16. HOWLAND, J., AND KRAMER, B.: Calcium and phosphorus in the serum in relation to rickets. Amer. J. Dis. Childhood, 22: 105 (1921).

17. JOWSEY, J.: Age changes in human bone. Clin. Orthop., 17: 210 (1960).

18. KEATING, F. R., JR., JONES, J. D., AND ELVEBACK, L. R.: Distri- 
bution of serum calcium and phosphorus values in unselected ambulatory patients. J. Lab. Clin. Med., 74: 507 (1969).

19. KNAPP, E. L., AND ROUTH, J. I.: Electrophoretic studies of plasma proteins in normal children. Pediatrics, 4: 508 (1949).

20. KUROKAWA, K.: Histological studies of normal and pathological human parathyroid glands. Jap. Med. World, 5: 241 (1925).

21. MARSHALL, R. W., AND NORDIN, B. E. C: The state of inorganic phosphate in plasma and its relation to other ions. In: Phosphate et me'tabolisme phosphocalcique: Regulation normale et aspects physiopathologiques (International Symposium, Paris, 1970), p. 127. (Laboratoires Sandox l'Expansion Scientifique, Paris, 1971)

22. MCLEAN, F. C, AND HASTINGS, A. B.: A biological method for the estimation of calcium ion concentration. J. Biol. Chem., 107: 337 (1934).

23. MOORE, E. W.: Ionized calcium in normal serum, ultrafiltrates, and whole blood determined by ion-exchange electrodes. J. Clin. Invest., 49: 318 (1970).

24. NELSON, W. E., VAUGHN, V. C, AND MCKAY, R. J.: Textbook of Pediatrics, Ed. 9, p. 1533. (W. B. Saunders Company, Philadelphia, 1969).

25. PERRIS, A. D., WHITFIELD, J. F., AND TÖLG, P. K.: Role of calcium in the control of growth and cell division. Nature, 219: 527 (1968)

26. PITTINGER, C, CHANG, P. M., AND FAULKNER, W.: Serum ionized calcium: Some factors influencing its level. South Med. J., 64: 1211 (1971).

27. PURNELl, D. C, SMITH, L. H., SCHOLZ, D. A., ELVEBACK, L. R., AND ARNAUD, C. D.: Primary hyperparathyroidism: A prospective clinical study. Amer. J. Med., 50: 670 (1971).

28. RADDE, I. C, PARKINSON, D. K., HÖFFKEN, B., APPIAH, K. E., AND HANLEY, W. B.: Ionized calcium levels in the newborn infant: Effect of bicarbonate treatment in patients with RDS and of exchange transfusions. Ann. Roy. Coll. Phys. Surg. Can., 8: 34 (1970).

29. REED, R. B., AND STUART, H. S.: Patterns of growth in height and weight from birth to eighteen years of age. Pediatrics, 24: 904 (1959).

30. REISS, E., CANTERBURY, J. M., BERCOWITZ, M. A., AND KAPLAN, E. L.: The role of phosphate in the secretion of parathyroid hormone in man. J. Clin. Invest., 49: 2146 (1970).

31. SACHS, C, BOURDEAU, A. M., AND PRESLE, V.: Ionised calcium measurement in whole blood: A new application of the calcium selective liquid membrane electrode. Rev. Eur. Etud. Clin. Biol., 16: 831 (1971).

32. SHERWOOD, L. M., MAYER, G. P., RAMBERG, C. F., JR., KRONFELD, D. S., AUERBACH, G. D., AND POTTS, J. T., JR.: Regulation of parathyroid hormone secretion: proportional control by calcium, lack of effect of phosphate. Endocrinology, 83: 1043 (1968).

33. SNEDECOR, G. W., AND COCHRAN, W. G., Statistical Methods, Ed. 6. (Iowa State University Press, Ames, Iowa, 1967).

34. STEARNS, G., AND WARWEG, E.: Studies of phosphorus of blood. I. The partition of phosphorus in whole blood and serum, the serum calcium and plasma phosphatase from birth to maturity. J. Biol. Chem., 102: 749 (1933).

35. STEENDIJK, R.: Metabolic bone disease in children. Clin. Orthop., 77: 247 (1971).

Copyright (C) 1973 International Pediatric Research Foundation, Inc.
36. TANNER, J. M., WHITEHOUSE, R. H., AND TAKAISHI, M. Standards from birth to maturity for height, weight, height velocity, and weight velocity: British children, 1965. Parts I and II. Arch. Dis. Childhood, 41: 454, 613 (1966).

37. TING-KAI, L., AND PIECHOCKI, J. T.: Determination of serum ionic calcium with an ion-selective electrode: Evaluation of methodology and normal values. Clin. Chem., 17: 411 (1971).

38. TRUDEAU, D. L., AND FREIER, E. F.: Determination of calcium in urine and serum by atomic absorption spectrophotometry (AAS). Clin. Chem., 1\}: 101 (1967).

39. TUMBLESON, M. E., HALL, M. W., BORKS, M. F., AND SPATE, M. P.: Blood values of Sinclair (S-1) miniature swine from 1 through 11 months of age (Abstract no. 87.). Read at the 21st Annual American Association for Laboratory Anima Science Meeting, Chicago, October 13-17, 1970.

40. WATSON, E. H., AND LOWREY, G. H.: Growth and Development of Children, Ed. 4, p. 179. (Year Book Medical Publishers, Inc., Chicago, 1962).

41. WIDDOWSON, E. M., AND DICKERSON, J. W. T.: Chemical composition of the body. In: C. L. Comar and F. Bronner: Mineral Metabolism: An Advanced Treatise, Vol. 2, Part A p. 128. (Academic Press, New York, 1964).

42. YOUNG, D. S.: Improved method for the automatic determination of serum inorganic phosphate. J. Clin. Pathol., 19: 397 (1966).

43. Vacutainer, Becton-Dickinson no. 4720 and no. 4783, Rutherford, N. J.

44. Perkin-Elmer model 303, Perkin-Elmer Corporation, South Pasadena, Calif.

45. Orion Research, Inc., Cambridge, Mass.

46. American Optical Corporation, Scientific Instrument Division, Buffalo, N. Y.

47. Technicon Corporation, Tarrytown, N. Y.

48. Sigma Chemical Company, St. Louis, Mo.

49. Enza-Trol, Dade Division American Hospital Supply Corporation, Miami, Fla.

50. Microliter equivalents are arbitrary units based on reference standard potency equal to $1,000 \mathrm{fd} \mathrm{eq} / \mathrm{ml}$.

51. The authors gratefully acknowledge the excellent technical assistance of Mary Jo Bill, Pamela A. Bonnes, Diane J. Brinck, Everette Jarvinen, Judith A. Larsen, Karen J. Laakso, Mary C. Matthusen, and Garry V. Mussmann. We also thank Miss Lee E. Fast and the nursing staff at the Russell M. Wilder Clinical Study Unit for their assistance with normal volunteers; and Ms. Kathlien M. Zwiefel and Ms. Barbara Patterson for their aid in preparation of the manuscript. Commentary by Doctors B. L. Riggs, Jr., and F. Glorieux was most helpful in completing this paper.

52. This investigation was supported in part by Research Grants AM-12302 and RR-585 from the National Institutes of Health, Public Health Service, and by a grant from the Mayo Foundation. Dr. Sara B. Arnaud completed this study during a Mayo Foundation Postdoctoral Fellowship.

53. Requests for reprints should be addressed to: SARA B. ARNAUD, M.D., Clinical Study Unit, Mayo Clinic, Rochester, Minn. 55901 (USA).

54. Accepted for publication December 19, 1972. 